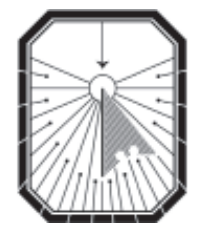

KYIV-MOHYLA

HuMANiTiES JOURNAL

KYIV-MOHYLA SCHOLARLY PEER-REVIEWED JOURNALS

\title{
Lesia Ukrainka's Crimean Cycles: A Poetic Dialogue with Adam Mickiewicz
}

Author(s): Yelena Severina

Source: Kyiv-Mohyla Humanities Journal 8 (2021): 69-83

Published by: National University of Kyiv-Mohyla Academy

http://kmhj.ukma.edu.ua/ 


\title{
Lesia Ukrainka's Crimean Cycles: A Poetic Dialogue with Adam Mickiewicz
}

\author{
Yelena Severina \\ University of California, Los Angeles, \\ Department of Slavic, East European and Eurasian Languages and Cultures
}

\begin{abstract}
This paper examines Lesia Ukrainka's two lyrical cycles about Crimea, Krymski spohady and Krymski vidhuky, as examples of a poetic dialogue with Adam Mickiewicz's Sonety krymskie. I begin my analysis by highlighting the different sensibilities of Mickiewicz's Sonety krymskie and Lesia Ukrainka's Krymski spohady, and underscore their formal and thematic peculiarities. The paper continues with an examination of Lesia Ukrainka's second cycle, Krymski vidhuky, as an experiment in drama - a genre that is absent from her first cycle - before situating a dramatic scene, "Ifiheniia v Tavridi," this cycle's only text about Crimea's Hellenic history, within the cultural contexts of Lesia Ukrainka's oeuvre. In doing so, I argue that Iphigenia's lament echoes the voice of an exiled poet from Mickiewicz's sonnets and conclude my analysis by probing reasons behind Lesia Ukrainka's choice of a Greek (not Tatar) heroine.
\end{abstract}

Key Words: Lesia Ukrainka, Adam Mickiewicz, Crimea, exile, poetic cycle, lesedrama, Iphigenia.

\section{(2)}

"Often in my thoughts I entertain great conversations with you, / While your eyes glare at me like a dream, those sad stars..." Lesia Ukrainka writes in a poem dedicated to Adam Mickiewicz, "Na motyv z Mitskevycha" (ca. 1893-1894; On a Motif from Mickiewicz). If one speculates on the topic of these imagined "conversations" between Ukraine's and Poland's national poets, Crimea emerges as one possibility insofar as it constitutes a shared theme of their lyrical cycles, albeit inspired by very different circumstances. Mickiewicz's participation in a secret student society at Vilnius University declared to be dangerous by the Russian imperial government led to his arrest in 1824 for "seeking to spread ill-advised Polish nationalism by means of teaching" and subsequent deportation to "provinces remote from Poland." After spending the final months of 1824 in St. Petersburg, Mickiewicz was exiled to Odesa in February of 1825. The following August, he undertook an excursion to Crimea together with his lover and some acquaintances. The result of the journey

1 Lesia Ukrainka, Zibrannia tvoriv u dvanadtsiaty tomakh [Collected Works in Twelve Volumes], vol. 1 (Kyiv: Naukova dumka, 1975), 230. 9-10. (Chasto ya $v$ dumtsi z toboiu velyki rozmovy provadzhu, / I svitiat, yak mriia, meni tvoi ochi, ti zori sumni...)

2 Roman Koropeckyj, Adam Mickiewicz: The Life of a Romantic (Ithaca: Cornell University Press, 2008), 54 . 
was Sonety krymskie (1826; Crimean Sonnets), a cycle of eighteen sonnets that describe what Mickiewicz called "the orient in miniature," with its exotic, enticing, and unforgiving nature. ${ }^{3}$ In contrast to what was by all accounts a pleasurable sojourn to the peninsula in the midst of the Polish poet's political exile, Lesia Ukrainka's multiple and prolonged stays in Crimea more than six decades later were aimed on improving her failing health. Two lyrical cycles, Krymski spohady (1890-1891; Crimean Recollections) and Krymski vidhuky (1897-1898; Crimean Echoes) became the fruits of her Crimean encounters, with the former cycle, in particular, eliciting comparisons with Mickiewicz. ${ }^{4}$ Lesia Ukrainka took up a residence in Crimea for the first time in July and August of 1890; for the second, in June and July of 1891; for the third, from June 1897 until June 1898; and for the fourth, from March 1907 until December 1908. Her final glimpse of Crimea occurred in 1913, when on account of her deteriorating health, she undertook a voyage to the Caucasus, which would become her final refuge, on a ship that briefly stopped at the ports of Yevpatoria, Sevastopol, and Yalta. ${ }^{5}$

By the time her second Crimean cycle was published, Lesia Ukrainka was already a notable figure on the Ukrainian literary scene, with Ivan Franko proclaiming in 1898 that, not since Taras Shevchenko had Ukraine heard "such a strong, passionate, and poetic voice.” Franko also recognized Lesia Ukrainka's earlier cycle of nine short poems, Podorozh do moria (1888; Voyage to the Sea), composed during her travels to Odesa several years before her first visit to Crimea, as a turning point in the poet's career, transcending as it did her preoccupation "with some sort of abstract human relations and abstract patriotism."7 Following Lesia Ukrainka's death in 1913, the generation of neoclassical poets undertook efforts to periodize her body of work, theorize about her style, examine influences in her poetry, and probe her fascination with foreign cultures. ${ }^{8}$ During this time too, Mickiewicz's Sonety krymskie drew their

$3 \quad$ Koropeckyj, Adam Mickiewicz, 68.

4 For comparative analyses of Mickiewicz's Sonety krymskie and Ukrainka's Krymski spohady, see the studies by Mykhailo Drai-Khmara, Maksym Rylskyi, Petro Odarchenko, Hryhorii Verves, Władysław Piotrowski, Rostyslav Radyshevskyi, Marian Jakóbiec, Natalia Yakubchak, and others.

5 See chronology in Olha Kosach-Kryvyniuk, Lesia Ukrainka: Khronolohiia zhyttia i tvorchosty [Lesia Ukrainka: A Chronology of Her Life and Works] (New York: The Ukrainian Academy of Arts and Sciences, 1970); see Crimean periodization in Mykhailo Vyshniak, "Zhanrova svoieridnist krymskoi liryky Lesi Ukrainky [Genre Peculiarities of Lesia Ukrainka's Crimean Lyrics]," in Lesia Ukrainka i suchasnist, vol. 4, book 1 (Lutsk: Volynskyi natsionalnyi universytet imeni Lesi Ukrainky, 2007), 12.

6 Ivan Franko, "Lesia Ukrainka," Literaturno-naukovyi vistnyk 7 (1898): 19. (Ukraina ne chula takoho sylnoho, horiachoho ta poetychnoho slova.)

7 Franko, “Lesia Ukrainka," 14. (Dosi vona liubuvalasia pryrodoiu, vitala $v$ sferi yakykhs abstraktnykh liudskykh vidnosyn i abstraktnoho patriotyzmu.)

8 For the monographs, see Mykola ZerovLesia Ukrainka. Krytychno-biohrafichnyi narys [Lesia Ukrainka: Critical-Biographical Essay] (Kharkiv; Kyiv, 1924) and Mykhailo DraiKhmara's Lesia Ukrainka: zhyttia i tvorchist [Lesia Ukrainka: Life and Works] (Kyiv: 
attention, as an exercise in translation - Mykola Zerov and Maksym Rylskyi both translated the cycle into Ukrainian - and, more importantly, as one of the chief inspirations of Lesia Ukrainka's Crimean oeuvre. ${ }^{9}$

This paper attempts to read Lesia Ukrainka's two Crimean cycles, written during the poet's first three visits to the peninsula at the beginning and end of the 1890 , as a response to Mickiewicz's Crimean lyrics. While Krymski spohady may be regarded as an explicit, indeed programmatic attempt at a dialogue with the Polish bard, almost begging a comparison between the two, Krymski vidhuky can also be read as an extension of this "conversation," a conversation that commences with Krymski spohady. My analysis begins with an investigation of Krymski spohady and Sonety krymskie, addressing these cycles' different narrative structures and emphasizing an important formal difference between them, namely, the absence of dramatic dialogue in Krymski spohady, a decision that demonstrates the slow movement in Lesia Ukrainka's poetry toward dramatic form. The analysis continues with a closer look at her second cycle, Krymski vidhuky, which can be described as an exercise in dramaturgy, and focuses on "Ifiheniiav Tavridi" (Iphigenia in Tauris, VI), the excerpt that represents Lesia Ukrainka's first attempt at a dramatic poem, and the only one that addresses Crimea's Hellenic history. The paper concludes with a comparison of Iphigenia's lament to the voice of an exiled poet from Mickiewicz's Sonety krymskie and considers reasons behind Lesia Ukrainka's choice of a Greek heroine and thus an intentional subversion of the cycle's Orientalist aesthetic.

Lesia Ukrainka's Krymski spohady was composed during the poet's first two stays in Crimea during the summers of 1890 and 1891, but published for the first time only two years later, in Lesia Ukrainka's first poetic collection Na krylakh pisen (1893; On the Wings of Songs). Inspirations for the cycle, which was dedicated to the poet's younger brother Mykhailo, include the poetry of Taras Shevchenko, Heinrich Heine, Alfred de Musset, and Aleksandr Pushkin. ${ }^{10}$ However, it is Mickiewicz's influence that is the most prominent, evidenced by Lesia Ukrainka's decision to give five poems in her collection the same titles as those in Sonety krymskie and structure the three poems

Derzhavne vydavnytstvo Ukrainy, 1926). For other monographs, see Andrii Muzychka and Mykola Zerov "Lesia Ukrainka. Yii zhyttia, hromadska diialnist i poetychna tvorchist [Lesia Ukrainka: Her Life, Public Activity, and Poetic Creativity]," Chervonyi shliakh 6-7 (1925): 327-30.

9 In addition to Krymski spohady, Ukrainka's literary engagement with Poland's national poet involves a translation of the "Wilja" song from the historical poem Konrad Wallenrod (1828) ("Z poemy Konrad Vallenrod" (ca. 1887)). "Why," asks Rylskyi, "did Ukrainka, a prolific translator and Ukraine's national poet, select this lyrical segment that fails to speak about the themes of struggle, political tyranny, social injustice, fate of one's own country, and resistance to authorities, all of which were close to her own heart?" Rylskyi, however, ventures no answer. See Maksym Rylskyi, Zibrannia tvoriv u dvadtsiaty tomakh [Collected Works in Twenty Volumes], vol. 14 (Kyiv: Naukova dumka, 1986), 378.

10 Drai-Khmara, Lesia Ukrainka, 74. 
about Bakhchysarai as sonnets." The genre of both Sonety krymskie and Krymski spohady can be described as poetic travelogues that share a fascination with such themes as the Orient, Crimea's Tatar past, and the sublime nature of the region's mountains, precipices, cliffs, storms, and untamable sea. Unlike Mickiewicz's cycle of sonnets, however, Lesia Ukrainka's thirteen - "Zaspiv" (An Introductory Song) and twelve numbered poems - are not restricted to any particular poetic form, thereby imbuing her cycle with the subjective quality of recollections, which, true to their nature, are often impressionable, chaotic, and fragmentary. Mykhailo Vyshniak notes that Lesia Ukrainka's poetic collection communicates impressions of a lyrical hero, in whom we can recognize the author herself, and represents an idiosyncratic poetic kaleidoscope of the state of the poet's soul, which is occupied with concerns for herself and mankind. ${ }^{12}$

This difference in form between Mickiewicz's Sonety krymskie and Lesia Ukrainka's Krymski spohady articulates two strikingly different sensibilities, which can be demonstrated by juxtaposing the poems from each collection that bear identical titles. For example, Mickiewicz's "Burza" (The Storm, IV) is the final of three poems depicting the voyage to Crimea in which the poet is still a traveler and not yet a pilgrim. It is a voyage permeated with the fear, anxiety, and mortal danger felt by a group of sailors negotiating a violent sea. As Wiktor Weintraub observes, in "Burza," as well as in the preceding two sonnets, "the landscape serves as the projection of [the poet's] state of mind." "13 The sonnet's concluding tercet introduces the only person aboard the boat who is not afraid of the raging tempest. He is a loner (thus, a quintessentially Romantic/Byronic hero) who contemplates his fate:

One traveler sat apart from the rest

Occupied with a thought: "Content is the one whose strength has left him,

Or the one who knows how to pray, or the one who has someone who'll miss him." ("Burza")14

11 "The calm of the sea": Mickiewicz's "Cisza morska” (II) and Ukrainka’s “Tysha morska (I)"; "Sailing”: Mickiewicz's "Żegluga” (III) and Ukrainka’s "Na chovni” (IV); “The storm”: Mickiewicz's "Burza” (IV) and Lesia Ukrainka’s "Nehoda” (V); "Baydary”: Mickiewicz's "Bajdary” (X) and Lesia Ukrainka’s "Baidary” (VII); "Bakhchysarai”: Mickiewicz's "Bakczysaraj" (VI) and Lesia Ukrainka's "Bakhchysarai” (IX). Lesia Ukrainka’s "Bakhchysaraiskyi dvorets" (Bakhchysarai's Castle, X) and "Bakhchysaraiska hrobnytsia" (Bakhchysarai’s Grave, XI) are compared with Mickiewicz's "Bakczysaraj w nocy” (Bakhchysarai at Night, VII) and "Grób Potockiej" (The Grave of Countess Potocka, VIII). See Drai-Khmara, Lesia Ukrainka, 74-75. While both Mickiewicz's Sonety krymskie and Ukrainka's three Bakhchysarai sonnets are all Petrarchan/Italian sonnets, Mickiewicz's are all with a Sicilian sestet (abba abba cdcdcd), while each one of Lesia Ukrainka's is different (abba baba ccdeed [French sestet]; abba abba ccddee; abba aabb ccdeed [French sestet]). Mykhailo Vyshniak, "Zhanrova svoieridnist," 15, 17.

13 Wiktor Weintraub, The Poetry of Adam Mickiewicz ('s-Gravenhage: Mouton, 1954), 101.

14 Adam Mickiewicz, Dzieła wszystkie, vol. 1, part 2, ed. Czesław Zgorzelski (Wrocław; Warszawa; Kraków; Gdańsk: Ossolineum, 1972), 19.12-14. (Jeden podróżny siedział w 
Throughout Mickiewicz's cycle, nature acts as a force that threatens, and hence poses existential questions to the cycle's central persona, the Polish Pilgrim, who is a stranger in Crimea and who must rely on Mirza, his indigenous companion, for guidance. As David Welsh points out, the sonnets are full of "cryptic warnings not to look, not to leap, not to proceed in a certain direction" as well as "images of water, darkness, and descent." ${ }^{15}$ They suggest that the Pilgrim's journey is one of initiation in "his quest for a deeper understanding of himself" as he makes his way through a series of encounters with the Orient. ${ }^{16}$

Unlike Mickiewicz's interpretation of a raging sea, Lesia Ukrainka's "Nehoda" (The Storm, V) presents neither a powerful confrontation between man and nature, nor any threat to the main character. A pensive poet calmly observes the storm a symbol of cleansing and purification - from the safety of her room where she ponders over the question of national oppression:

Like a wrecked ill-fated boat

Perishes in yellow sands,

So does this wondrous, God-given land

Perish at the hands of others.

$\cdots$

Mighty sea! Gather your strength!

You are powerful, you are unconstrained, -

Disperse your riotous waves,

Flood this desolate land! ("Nehoda”) ${ }^{17}$

Lesia Ukrainka's desire to see Crimea perish rather than remain in the hands of its captors underscores a motif that will continue to be rearticulated in her works: it is more honorable to die fighting than to live in captivity. Like Mickiewicz's disillusioned traveler in a foreign land, she also conveys feelings of frustration and profound loneliness in her Crimean lyrics. Serhii Yefremov highlighted the latter characteristic when describing Lesia Ukrainka's poetry as a poetry of loneliness (poeziia samotnosti). ${ }^{18}$ According to Vyshniak, nature in this poetic cycle acts as a spiritual and material catalyst through contact with which the poet finds strength and resilience in

milczeniu na stronie / I pomyślit: szczęśliwy, kto sity postrada, / Albo modlić się umie, lub ma się z kim żegnać.)

15 David J. Welsh, Adam Mickiewicz (New York: Twayne Publishers, 1966), 49.

16 Welsh, Adam Mickiewicz, 51.

17 Ukrainka, Zibrannia tvoriv, vol. 1, 104.17-20 and 105.33-36. (Yak rozbytyi choven beztalannyi / Sered zhovtykh piskiv pohybaie, / Tak chudovyi sei krai bohodannyi / U nevoli v chuzhykh propadaie. ... Sylne more! zberysia na syli! / Ty potuzhne, nema tobi vpynu, - / Rozzheny svoi buinii khvyli, / Zatopy siu neshchasnu krainu!) 
confronting both her own illness and the injustice that is taking place in society. ${ }^{19}$ Unlike Mickiewicz's traveler, however, Lesia Ukrainka's lyrical heroine chooses to remain largely a passive observer as opposed to a participant. By intentionally maintaining her distance from nature in order to preserve her safety, the poet has no profound experiences of the sublime.

The second important difference between these cycles is a formal one - the presence of dramatis personae in Mickiewicz's Sonety krymskie and the absence thereof in Lesia Ukrainka's Krymski spohady. With a tradition pioneered by an embittered Ovid, exiled by the emperor Augustus to the shores of the Black Sea, the motif of permanent loss dominates Mickiewicz's work and is, in a sense, a selfdramatization. The Polish poet's personae are the characters of the Pilgrim and Mirza who converse in two sonnets: "Widok gór ze stepów Kozłowa" (A View of the Mountains from the Steppes of Kozlov, V) and "Droga nad przepaścią w Czufut-Kale" (The Road Along the Precipice of Çufut Kale, XV). Additionally, each of these characters has a monologue - Mirza in "Czatyrdah" (Chatyr-Dag, XIII), "Mogity Haremu” (The Graves of the Harem, IX), "Góra Kikineis" (Mount Kikineis, XVI), and the Pilgrim in "Pielgrzym" (The Pilgrim, XIV). Their relationship is crucial to the cycle since it is through his contact with a Westerner that Mirza too is enlightened. Izabela Kalinowska-Blackwood asserts that the appearance of both of these characters in the fifth sonnet signifies the beginning of the "dialogical journey" for the rest of the cycle: the subsequent three sonnets, which focus on Bakhchysarai and Countess Potocka's grave, present Crimea from the Pilgrim's perspective, with Mirza's voice returning again in the ninth sonnet and on. ${ }^{20}$ Whether we choose to read their relationship as one, per KalinowskaBlackwood, between a Westerner and an oriental Other ${ }^{21}$ or, per Roman Koropeckyj, as two speaking the same language after Mirza internalizes "the 'lesson' in sensibility proffered by his aesthetically 'sophisticated' Westerner," ${ }^{22}$ their presence contributes to the cycle's continuous narrative about Crimea, strengthens the cycle's structure and cohesion. No such narrative exists in Lesia Ukrainka's Krymski spohady. It will, however, emerge strongly in her second Crimean cycle when, according to Zerov, Lesia Ukrainka abandons "lyrical responses" (lirychni vidhuky) in favor of monologues, dialogues, and dramatic scenes. ${ }^{23}$ To be precise, Zerov details this preoccupation with drama that begins with monologue, moves from monologue to dialogue, from dialogue to dramatic poem, and finally, toward the end of Lesia Ukrainka's life, to drama proper, such as Lisova pisnia (1911; The Forest Song) and Kaminnyi hospodar (1912; The Stone Host). ${ }^{24}$

19 Vyshniak, "Zhanrova svoieridnist," 17.

20 Izabela Kalinowska-Blackwood, "The Dialogue between East and West in the 'Crimean Sonnets," The Polish Review 43.4 (1998): 431.

$21 \quad$ Kalinowska-Blackwood, "The Dialogue," 436.

22 Roman Koropeckyj, "Orientalism in Adam Mickiewicz's Crimean Sonnets," SEEJ 45.4 (2001): 669 .

23 Mykola Zerov, "Lesia Ukrainka," in Tvory v dvokh tomakh, vol. 2 (Kyiv: Dnipro, 1990), 374 .

24 Zerov, "Lesia Ukrainka," 389. 
If the lack of dramatization in Krymski spohady presents an author who, at this point in her career, was still not interested in or hesitant to experiment with a dramatic genre, so integral to the Polish cycle that inspired her, it is during Lesia Ukrainka's next visit in Crimea, six years later in 1897, that a definitive shift from poetry to drama takes place. By this time, she was already somewhat familiar with playwriting, having a year before composed her first dramatic texts in prose, Blakytna troianda (1896; The Azure Rose) and Proshchannia (ca. 1896; Farewell). Her second Crimean cycle, Krymski vidhuky, was written during a year-long stay in Crimea and published as part of the collection Dumy i mrii (1899; Thoughts and Dreams). ${ }^{25}$ In a letter to Olha Kobylianska on May 20, 1899, Lesia Ukrainka complained about the arduous task of assembling the texts she had written - six poems and the dramatic scene - into a cycle and compared the endeavor to chiseling stone. ${ }^{26}$ It was also during this visit to Crimea, when Lesia Ukrainka practiced translating short dramatic excerpts from Shakespeare's Macbeth and Lord Byron's Cain, but, as with one of the cycle's texts, "Ifiheniia v Tavridi" (VI), these translations remain incomplete. The choice of Byron's Cain, as well as the brieflyconsidered Manfred, is significant since both works, like "Ifiheniia v Tavridi" (VI), belong to the genre of closet drama (Lesedrama).

In contrast to Lesia Ukrainka's earlier Crimean cycle, wherein each poem is an individual poetic expression, every text of the second cycle is infused with dramatic essence. "Improvizatsiia" (Improvisation, I), a love poem, opens the cycle and introduces Crimea's exotic landscape, its nature anthropomorphized. The choice of blank verse suggests Lesia Ukrainka's intention, quite literally, to improvise and free herself from the restricted confines of rhymed poetry. The refrain in the penultimate line of each of the four stanzas ("Sleep, my heart!"27) resounds like the promised echo in the cycle's title and imbues the piece with a musical quality. This poem is followed by "Uryvky z lysta" (Excerpts From a Letter, II) - dedicated to Ivan Steshenko ${ }^{28}$ and composed in vers libre - an epistolary text that can also be read as a dramatic monologue. In the poem's first two lines, Lesia Ukrainka warns about her departure from the poetic norm: "My comrade! Do not be amazed by this lazy verse / Rhymes, the daughters of sleepless nights, are abandoning me." ${ }^{29}$ These "lazy" unrhymed lines of varying length continue to relay the poet's fascination with Crimean nature and culminate in the

25 Composed chronologically, the first five poems were written at the end of 1897, followed by "Ifiheniia v Tavridi" (VI) and "Vesna zymova" (VII) in the early months of 1898. See Kosach-Kryvyniuk, Lesia Ukrainka, 424, 461. Subsequently, "Skhidna melodiia” (III), "Mrii” (IV), and "Zymova nich na chuzhyni” (V) were published in separate volumes of Literaturno-naukovyi vistnyk (Literary-Scholarly Herald) in 1898. "Skhidna melodiia" (III) and "Mrii" (IV) were published in Book 2; "Zymova nich na chuzhyni” (V) in Book 5. See Ukrainka, vol. 11, 391.

26 Kosach-Kryvyniuk, Lesia Ukrainka, 112-13. (... robota sia ide, yak z kaminnia.)

27 Ukrainka, Zibrannia tvoriv, vol. 1, 156. 6, 156.14, 156.22, and 156.31. (Spy, moie sertse!)

28 Ukrainka, Zibrannia tvoriv, vol. 12, 98.

29 Ukrainka, Zibrannia tvoriv, vol. 1, 157.1-2. (Tovaryshu mii! ne zdyvuite z linyvoho virsha. / Ryfmy, dochky bezsonnykh nochei, pokydaiut mene.) 
poem's second part wherein she describes her travels up the mountain of Ai-Petri. Unlike Mickiewicz's Pilgrim, who looks into the abyss in "Droga nad przepaścią w Czufut-Kale” (XV), Lesia Ukrainka's lyrical hero is again not destined to experience the sublime or confront fears on her journey into what she depicts as a prison-like landscape interminably scorched by the sun. Hers is a revelation of a different kind - a flower (saxifraga) that grows through stones (saxum "stone," frangere "to break"), which is mightier than a century-old oak as it defiantly survives in this unforgiving landscape. On the one hand, the invocation of the Promethean theme of struggling against all odds demonstrates the author's determination not to succumb to her illness; on the other, the relentless flower symbolizes, per Rylskyi, the poet's oeuvre, which in itself is a "breaker of stones" (lomykamin) in Ukrainian literature..$^{30}$

Written shortly after Serhii Merzhynskyi's departure from Yalta, the cycle's next poem "Skhidna melodiia" (An Oriental Melody, III) is a love poem that employs Orientalist imagery. With four quatrains of varying rhyme schemes, it depicts a poet donning a Tatar dress as she waits for her significant other: "My beloved! I will wait for you / While wrapped in a black, dim veil." ${ }^{11}$ She then makes a promise to plant a cypress branch, which, watered by her tears, will grow into a tree towering over the minarets. This poem is followed by "Mrii" (Dreams, IV), which is written in blank verse and is replete with images and songs from Lesia Ukrainka's childhood. The poet tells us about her love for the Middle Ages and fearless knights who represent the moral ideal of men fighting for freedom - they would rather lose their lives than surrender. The fifth poem, "Zymova nich na chuzhyni" (A Winter Night in a Foreign Land, V), which was later dedicated to Lesia Ukrainka's friend Mykhailo Kryvyniuk, ${ }^{32}$ is a dramatic dialogue between the poet and her muse. The muse suggests different themes to the disenchanted poet who rejects them all and resolves to wait until spring, which is when she vows to write poetry that will have a higher purpose. 33 The cycle concludes with "Ifiheniia $\mathrm{v}$ Tavridi" (VI) and "Vesna zymova” (Wintry Spring, VII). "Vesna zymova," also written in free verse and dedicated to Kryvyniuk, ${ }^{34}$ synthesizes many of the cycle's previous themes. Set during an unusually warm winter evening, it depicts the restless poet who paces her balcony, unable to sleep or work. She admires the winter landscape in moonlight and thinks about Ukraine, her family, and her friends back home. That said, it is the penultimate text, "Ifiheniia v Tavridi" (VI) - an adaptation of the opening scene from Euripides' tragedy - that is this cycle's culmination. Defined by Lesia Ukrainka as a "dramatic scene" (dramatychna stsena), this attempt at a full-fledged drama formally and thematically challenges the cycle's homogeneity.

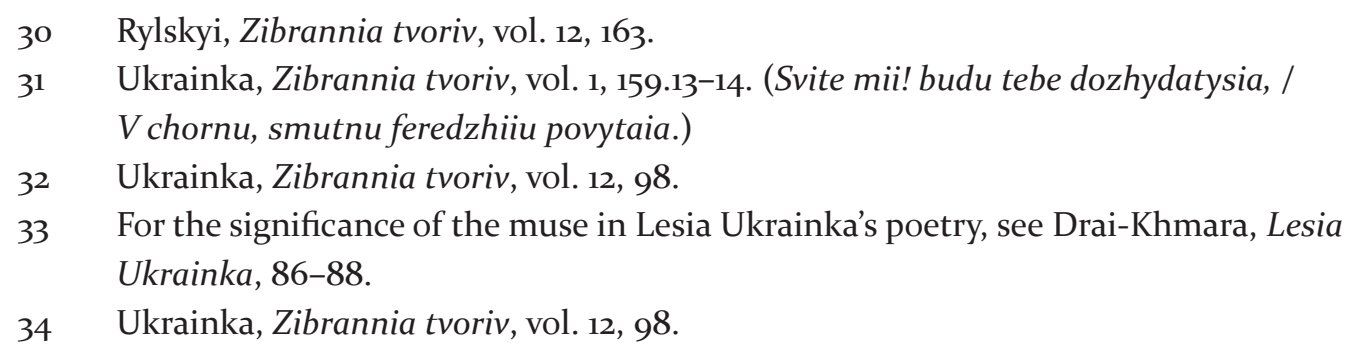


Lesia Ukrainka composed "Ifiheniia v Tavridi" (VI) during her stay in Yalta at Villa Iphigenia, a circumstance which no doubt led her to consider the popular myth. ${ }^{35}$ After working on the scene over several days and finishing it on January 15 , 1898 , the ailing poet must have felt an affinity for the exiled heroine, whose experience of being separated from her family and friends paralleled her own..$^{66}$ In a letter to her mother, the writer Olena Pchilka, nearly two weeks later, on January 27, Lesia Ukrainka writes that the work on the play stopped ("Ifiheniia' chohos spynylasia") but does not elaborate on the reasons. ${ }^{37}$ She thus completed only two short parts, the chorus of young girls in front the goddess's altar and the heroine's lament. With Goethe's poetry and, particularly, his poem Prometheus (1785) as major influences on Lesia Ukrainka's poetry, her Iphigenia identifies herself as a descendant of Prometheus (nashchadka Prometeia) but, perhaps because the piece remains unfinished, she does not quite (or yet) emerge as a Promethean heroine. ${ }^{38}$ Similarly, the only likeness between Goethe's Iphigenia (Iphigenie auf Tauris, 1779-1787) and Lesia Ukrainka's interpretation of the myth is that both writers focus on their heroine's psychological portrait. ${ }^{39}$

The main influence on Lesia Ukrainka's Iphigenia remains Euripides, the first one to narrate the story of this character's predicament in Tauris - Taurida or Tavrida, present-day Crimea - where Iphigenia served as Artemis's priestess. Although written last, Iphigenia in Aulis (ca. $410 \mathrm{BC}$ ) is his first installment of the well-known myth. The tragedy relates the story of King Agamemnon, who must offer his daughter, Iphigenia, as a sacrifice in recompense to the goddess Artemis for slaughtering her sacred deer. In exchange for his daughter's life, the goddess, who had hindered the king's voyage to Troy by quelling favorable winds, agrees to restore the winds and sea currents so that the king and his men can sail from Aulis to Troy. Agamemnon orders Iphigenia to be fetched with the promise of her betrothal to Achilles but instead offers her up as a sacrifice on the goddess's altar. At the last moment, however, Artemis takes pity on the girl, spirits her away in a cloud to Tauris, and puts a deer in her place. Iphigenia in Tauris (ca. 414-412 BC) chronologically continues the story of

35 For the analysis of "Ifiheniia v Tavridi" (VI), see works by Svitlana Kocherha, Lina Kostenko, Svitlana Vynar, Oleksandra Visych, Yurii Hanoshenko, Tereza Levchuk, Yuliia Levchuk, Liubov Starodubtseva, Olha Turhan, Viktor Humeniuk, and others. The dramatic scene is usually presented as a precursor to Ukrainka's more accomplished dramatic oeuvre, beginning with Oderzhyma (1901; A Woman Possessed). Lesia Ukrainka's comrades from political circles urged her to leave the country at this time, thus diminishing the possibility of her arrest, incarceration, or exile, which would have further jeopardized her health. See Oleh Babyshkin, Dramaturhiia Lesi Ukrainky [Lesia Ukrainka's Dramaturgy] (Kyiv: Derzhavne vydavnytstvo obrazotvorchoho mystetstva i muzychnoii literatury, 1963), 50. Ukrainka, Zibrannia tvoriv, vol. 11, 17.

38 See, for example, Albert Kipa "Pro deiaki aspekty tvorchoho protsesu Lesi Ukrainky i Gete [On Some Aspects of Creative Process of Lesia Ukrainka and Goethe]," accessed June 27, 2021, https://www.l-ukrainka.name/uk/Studies/Goethe.html. Babyshkin, Dramaturhiia Lesi Ukrainky, 47. 
Iphigenia's life as Artemis's priestess, wherein her duty is to sacrifice sailors shipwrecked on the shores of Tauris. After Iphigenia's brother, Orestes, and his friend, Pylades, become stranded in Tauris, the brother and sister are reunited and eventually escape..$^{\circ}$

Lesia Ukrainka originally planned on writing a drama in two acts with a cast of characters that included Orestes and Pylades, hence presumably also depicting the escape from Tauris. In a letter to her mother from January 21, 1898, less than a week after starting her work on the play, the poet recounts her preoccupation with the play's formal features: “Ifiheniia' will not be a kind of new drama: it will have a chorus, a replica a parte and perhaps even deus ex machina!" ${ }^{41}$ She then identifies its genre as a lesedrama, in part, perhaps, because of Iphigenia's lengthy speech. "The monologue, as I can judge myself, is frightfully long," Lesia Ukrainka writes, "and could be shortened if staged (!) but should be alright if the piece is read instead. If this were a domestic drama, such a monologue would not be acceptable, but it is fine for a dramatic poem en style classique." 42 Despite this "frightfully long" monologue, in the spirit of ancient Greek tragedies, Lesia Ukrainka modernizes other aspects of the dramatic fragment. When compared side by side, Lesia Ukrainka's text and the opening scene of Euripides' tragedy (incidentally, of Goethe's as well) differ formally in how they introduce the heroine. Euripides achieves the latter with two short sentences: "Before the door of the temple of Artemis, in the Taurian country. Enter [Iphigenia], alone, to speak the prologue."43 In contrast to this terse introduction, Lesia Ukrainka's authorial remarks in her opening are replete with descriptions of the Crimean landscape. Along with laurels, magnolias, olive trees, and cypresses, she includes such details about the goddess's temple as its altar and fire, the sea with its cliffs and rocks, and the marble path leading from the temple to the shore. As the play progresses, these details enter Iphigenia's soliloquy as she reminisces about the past, her home, and family. This is the case, for instance, when the heroine leans her head against a stone column, a move which elicits memories of her previous life:

$40 \quad$ See The Dictionary of Classical Mythology, ed. Pierre Grimal, s.v. "Iphigenia." Although less popular than Iphigenia in Aulis and criticized for its failure to fulfill a tragedy's function (per Aristotle, to excite fear and pity), the story of Iphigenia's exile captivated generations of artists. For the history of this myth in the arts, see Edith Hall Adventures with Iphigenia in Tauris: A Cultural History of Euripides' Black Sea Tragedy (New York: Oxford University Press, 2013).

41 Ukrainka, Zibrannia tvoriv, vol. 11, 16. Original italics.

42 Ukrainka, Zibrannia tvoriv, vol. 11, 16. Original italics and punctuation.

43 Euripides, Iphigeneia in Tauris, trans. Richmond Lattimore (Oxford: Oxford University Press, 1973), 13. In his Foreword to Latimore's translation, William Arrowsmith clarifies that since the ancient manuscripts of the Greek plays do not supply us with stage directions, those must be inferred from words, situations, and knowledge of Greek theatrical conventions. Ibid., ix. 
Cold marble is my only refuge!

And how I used to lean my head,

Against my beloved mother's chest

And listened to the heartbeat... ("Ifiheniia v Tavridi") 44

The elements of the setting, of which Iphigenia is aware and with which she interacts, as if they were people, emphasize her loneliness and need for human contact. As for the authorial remarks, which introduce these objects, they not only underscore the play's genre of lesedrama, but, according to Svitlana Vynar, help to elicit meaning from the dramatic scene, as with the aforementioned marble path, for instance, which symbolizes the respect of the ancient people of Tauris toward Artemis. ${ }^{45}$ The decision not to shorten Iphigenia's monologue must have bothered Lesia Ukrainka, who expressed hope that her mother and Mykhailo Starytskyi "would not think that [she] had renounced [her] principle of excluding monologues from a new drama." ${ }^{6}$ This reassurance demonstrates Lesia Ukrainka's search for new forms of theater, a chief preoccupation of all modernist playwrights during the fin de siècle. ${ }^{47}$

Other differences between Euripides' and Lesia Ukrainka's treatments of the myth concern details of the plot. Euripides' Iphigenia begins her monologue with the backstory of her father's betrayal before speaking about her dream, in which she finds herself in Argos and where she sees her house collapse except for a single pillar that she then sprinkles with water. She misinterprets her dream to mean that her brother is dead: the pillar represents her brother, and the water ritual reminds her of her duty at Tauris to sacrifice shipwrecked travelers. Distraught, Iphigenia laments her inability to properly bury Orestes: "I wish, then, to attend the absent, give my brother / his last rites. So much I can do for him." ${ }^{48}$ A different picture emerges in Lesia Ukrainka's dramatic scene, wherein the exposition commences not with Iphigenia but with the chorus of girls, who sing praises to Artemis before introducing Iphigenia as "the dearest priestess of their goddess" (bohyni zhrytsia naimylisha). After the chorus exits, Lesia Ukrainka's heroine begins a speech that deals neither with dreams nor with family but,

44 Ukrainka, Zibrannia tvoriv, vol. 1, 168 (Kholodnyi marmur - tilky zh i prytulku! A yak bulo ya holovu skhyliala / Do materi kokhanoi na hrudy / I slukhala, yak ridne sertse bylos...)

45 Svitlana Vynar, "Komunikatyvna rol remarky v 'drami dlia chytannia' [Communicative Role of Note in 'Drama for Reading']," Naukovi zapysky Natsionalnoho universytetu 'Ostrozka akademiia.' Seriia 'Filolohichna' 54 (2015): 156.

46 Ukrainka, Zibrannia tvoriv, vol. 11, 16. (... ne dumaly, niby ya zreklas svoho pryntsypu vykliuchennia monolohiv z novitnoi dramy.)

47 Despite the play being left unfinished, as well as it not being written for the stage, Lesia Ukrainka was pleasantly surprised to see it performed along with her other dramatic monologue Saul (1900) at Mykola Lysenko's Music and Drama School during her brief stay in Kyiv after returning from Egypt in 1910. See Anatol Kostenko, Lesia Ukrainka (Kyiv: A.S.K, 2006), 337.

48 Euripides, Iphigeneia in Tauris, 14.61-62. 
rather, with home: "In my heart it is only you, / My only, beloved native land!"49 Characteristically for a poet concerned more with national issues than personal ones, Iphigenia's Greece emerges as a metaphor for Lesia's Ukraine:

Argos, my dear country!

I would rather die a hundred times,

Than to live here! Waters of Styx and Leta

Will not extinguish recollections of my beloved land!

("Ifiheniia v Tavridi") $)^{50}$

The scene's climactic moment, which is conveyed primarily through authorial remarks than Iphigenia's own words, arrives when the heroine, in despair over her destiny to never again return home, intends to end her life. It is at this moment that she remembers her spiritual connection to Prometheus and expresses the readiness to die for her country if this is indeed her destiny. "Heavy is your legacy, Father Prometheus!" Iphigenia cries. ${ }^{11}$

"Ifiheniia v Tavridi" (VI) thus fits organically within the second cycle's dramatic structure, constituting as it does yet another manifestation of the author's intent to write poetic dramas. As for its heroine, Iphigenia is presented as someone whose voice also echoes the second cycle's leitmotif, which, according to Vyshniak, is one's constant readiness to act, to persevere, to struggle, in spite of any obstacles, physical illnesses or momentary depression..$^{52}$ But several important questions remain: why includea Hellenic heroine into a cycle with - granted, somewhat muted but nonetheless still present Orientalist imagery? Why not publish the dramatic scene separately? Almost a decade later, during her final stay in Crimea in 1907, Lesia Ukrainka would, in fact, compose a dramatic dialogue, Aisha ta Mokhammed (Aisha and Mohammed), inspired by the important personalities in the history of Islam. ${ }^{33}$ However, at the time of her work on the second Crimean cycle, the poet sought inspiration in Ancient Greece. In this respect, Lesia Ukrainka's approach could not have been more different than Mickiewicz's, whose Crimean lyrics completely elide the peninsula's Classical Greek past. The decision of this classically trained poet to write about the Orient rather than the world of Greek and Roman myths was, according to Koropeckyj, meant to aggravate "the delicate ears of the [Warsaw] classicists," who largely ignored Mickiewicz's previous two volumes of poetry and for whom his sonnet cycle represented "a provocative challenge to literary taste."54

49 Ukrainka, Zibrannia tvoriv, vol. 1, 168. (A v sertsi tilky ty, / Yedynyi mii, kokhanyi ridnyi kraiu!)

50 Ukrainka, Zibrannia tvoriv, vol. 1, 170. (Arhose, ridnyi mii! / Volila b ya sto raz umerty, /

Nizh tuta zhyty! Vody Stiksa i Lety / Ne vhasiat spohadiv pro liubyi ridnyi krai!)

51 Ukrainka, Zibrannia tvoriv, vol. 1, 170. (Tiazhkyi tvii spadok, batku Prometeiu!)

52 Vyshniak, "Zhanrova svoieridnist," 25-26.

53 Lesia Ukrainka's lyrical cycle Vesna $v$ Yehypti (1910; Spring in Egypt) is another work that was inspired by the Muslim world.

54 Koropeckyj, Adam Mickiewicz, 80. 
Lina Kostenko's description of Iphigenia's lament as a "Ukrainian model of nostalgia," made poignant by her expression of longing "for home while at home," provides some ideas for interpreting Lesia Ukrainka's decision to focus on a Greek heroine and for likening Iphigenia's lament to the lyrical voice of the exiled poet from Mickiewicz's Sonety krymskie. ${ }^{55}$ Both poets speak of exile from the point of view of their exiled characters; one can thus read in the words of the Greek heroine in a Tatar land Lesia Ukrainka's response to Mickiewicz's symbolic autobiography, as encoded in his Crimean cycle. ${ }^{6}$ Like Iphigenia's pain at being forced to remain away from her home against her will, the Polish poet's longing for Lithuania resonates throughout his Crimean cycle, beginning with the concluding lines of the first sonnet, "Stepy akermańskie" (The steppes of Ackerman, I), in which Mickiewicz sets out to Crimea from an area west of Odesa: "In silence I strain my ear to hear a voice from Lithuania. - Time to go. No one is calling." 57 The poet again thinks about his home in the sonnet about Countess Maria Potocka's grave, "Grób Potockiej" (VIII), who, like Iphigenia, was torn away from her homeland, just as he projects Potocka's fate onto his own: "I too will finish my days in solitary mourning."58

In contrast to Mickiewicz's interpretation of the famous legend, Lesia Ukrainka's "Bakhchysaraiska hrobnytsia” (Bakhchysarai’s Grave, XI) does not dwell upon Potocka's ordeal in the harem of the Tartar khan but, rather, she manipulates the story about the captured Polish countess to assert her distinctive poetic voice. Rylskyi, in fact, considers the final lines of "Bakhchysaraiska hrobnytsia" (XI) as key for understanding how Lesia Ukrainka challenges not only Mickiewicz, but also Pushkin as the author of Bakhchisaraiskii fontan (1820; The Fountain of Bakhchysarai) and the Polish poet's interlocutor ${ }^{59}$ :

No, this is not where the harem's beauty lies,

Neither doomed Maria nor passionate Zarema, -

The glory of Bakhchisarai rests here! ("Bakhchysaraiska hrobnytsia") ${ }^{60}$

55 Lina Kostenko, "Poet, scho ishov skhodamy hihantiv (skorocheno) [A Poet, Who Went Along the Stairs of Giants (abridged)]," in Ukrainske slovo: khrestomatiia ukrainskoi literatury ta literaturnoi krytyky XX stolittia, vol. 1 (Kyiv: Akonit, 2001), 181. (Tutukrainska model nostalhii. Tym boliuchisha, shcho ukraintsiu chasom dovodytsia vidchuvaty tuhu za batkivshschynoiu na batkivshchyni.)

56 For Mickiewicz's symbolic autobiography, see Hryhorii Hrabovych "Symvolichna avtobiohrafiia u Mitskevycha i Shevchenka [Mickiewicz's and Shevchenko's Symbolic Autobiography]," in Shevchenko, yakoho ne znaiemo by Hryhorii Hrabovych (Kyiv: Krytyka, 2000), 52-67.

57 Mickiewicz, Dzieła, 17.13-14. (W takiej ciszy - tak ucho natężam ciekawie, / Że styszałbym glos z Litwy. - Jedźmy, nikt nie woła.)

58 Mickiewicz, Dzieła, 21.9. (... ja dni skończę w samotnéj żałobie). Incidentally, this is the only sonnet in the cycle that references Pushkin's poem about the fate of a Polish countess.

59 Rylskyi, Zibrannia tvoriv, vol. 14, 378.

6o Ukrainka, Zibrannia tvoriv, vol. 1, 108.12-14. (Ni, tuta ne lezhyt krasa harema, / Mariia smutna chy palka Zarema, _/ Tut spochiva bakhchisaraiska slava!) 
It is not through the "doomed Maria" of the first Crimean cycle but through the resilient Iphigenia of the second - a character who compares her existence to a restless shadow but who is determined to persevere - that Lesia Ukrainka answers the Polish Romantic.

Weintraub argues that Mickiewicz's cycle, Sonety krymskie, at times "points backwards, to his preceding cycle [Sonety Odeskie (1825-1826; Odesa Sonnets)]," with both cycles forming a kind of unity. ${ }^{61}$ Similarly, Lesia Ukrainka's Krymski spohady "points backwards" to Krymski vidhuky, and the two cycles can be regarded as forming a larger work. While Mirza serves as the Pilgrim's Tatar guide through the exotic landscape in the Polish cycle, the poet in Krymski spohady does not seek a guide. In Krymski vidhuky, the poet again searches not for a guide but for a sympathetic ear: a friend back home in "Uryvky z lysta" (II), an obliging muse in "Zymova nich na chuzhyni” (V), or through Iphigenia's soliloquy. Although the choice of a Greek heroine defies the reader's expectations of the cycle's Orientalist imagery, Iphigenia represents a conscious decision on the writer's part to relay personal suffering through another exile's experience. Her lyrical voice, like the voice of the poet in Mickiewicz's Sonety krymskie, conveys the pain of separation from the home country and transforms it into the cycle's main theme. In this regard, Mickiewicz's sonnets are about the birth of a poet, while Lesia Ukrainka's Krymski vidhuky is about the birth of a playwright.

\section{Bibliography}

Babyshkin, Oleh. Dramaturhiia Lesi Ukrainky [Lesia Ukrainka’s Dramaturgy]. Kyiv: Derzhavne vydavnytstvo obrazotvorchoho mystetstva i muzychnoi literatury, 1963.

Drai-Khmara, Mykhailo. Lesia Ukrainka: zhyttia i tvorchist [Lesia Ukrainka: Life and Works]. Kyiv: Derzhavne vydavnytstvo Ukrainy, 1926.

Franko, Ivan. "Lesia Ukrainka." Literaturno-naukovyi vistnyk 7 (1898): 6-28.

Hrabovych, Hryhorii. "Symvolichna avtobiohrafiia u Mitskevycha i Shevchenka [Mickiewicz's and Shevchenko's Symbolic Autobiography]." In Shevchenko, yakoho ne znaiemo by Hryhorii Hrabovych, 52-67. Kyiv: Krytyka, 2000.

Euripides. Iphigeneia in Tauris. Translated by Richmond Lattimore. Oxford: Oxford University Press, 1973.

Kalinowska-Blackwood, Izabela. "The Dialogue between East and West in the "Crimean Sonnets." The Polish Review 43.4 (1998): 429-39.

Kipa, Albert. "Pro deiaki aspekty tvorchoho protsesu Lesi Ukrainky i Gete [On Some Aspects of Creative Process of Lesia Ukrainka and Goethe]." Accessed June 27, 2021. https://www. l-ukrainka.name/uk/Studies/Goethe.html.

Kocherha, Svitlana. Ifiheniia $v$ Tavridi: storinky krymskoho litopysu Lesi Ukrainky [Iphigenia in Tauris: Pages from Lesia Ukrainka's Crimean Chronicle]. Simferopol: Krymnavchpedderzhvidav, 1998.

Koropeckyj, Roman. Adam Mickiewicz: The Life of a Romantic. Ithaca: Cornell University Press, 2008.

Koropeckyj, Roman. “Orientalism in Adam Mickiewicz's Crimean Sonnets.” SEEJ 45.4 (2001): $660-78$. 
Kosach-Kryvyniuk, Olha. Lesia Ukrainka: Khronolohiia zhyttia i tvorchosty [Lesia Ukrainka: A Chronology of Her Life and Works]. New York: The Ukrainian Academy of Arts and Sciences, 1970.

Kostenko, Anatol. Lesia Ukrainka. Kyiv: A.S.K, 2006.

Kostenko, Lina. "Poet, scho ishov skhodamy hihantiv (skorocheno) [A Poet, Who Went Along the Stairs of Giants (Abridged)]." In Ukrainske slovo: khrestomatiia ukrainskoi literatury ta literaturnoi krytyky XX stolittia. Vol. 1, 180-90. Kyiv: Akonit, 2001.

Mickiewicz, Adam. Dzieła wszystkie. Vol. 1. Part 2. Edited by Czesław Zgorzelski. Wrocław; Warszawa; Kraków; Gdańsk: Ossolineum, 1972.

Rylskyi, Maksym. Zibrannia tvoriv u dvadtsiaty tomakh [Collected Works in Twenty Volumes]. Kyiv: Naukova dumka, 1983-1990.

Ukrainka, Lesia. Zibrannia tvoriv u dvanadtsiaty tomakh [Collected Works in Twelve Volumes]. Kyiv: Naukova dumka, 1975-1979.

Visych, Oleksandra, Estetyka non-finito u tvorchosti Lesi Ukrainky: monohrafiia [Non-Finito Aesthetics in Lesia Ukrainka's Writings: A Monograph]. Lutsk: PVD Tverdynia, 2014.

Vynar, Svitlana. "Komunikatyvna rol remarky v 'drami dlia chytannia' [Communicative Role of Note in 'Drama for Reading']." Naukovi zapysky Natsionalnoho universytetu 'Ostrozka akademiia.' Seriia 'Filolohichna' 54 (2015): 155-57.

Vyshniak, Mykhailo. "Zhanrova svoieridnist krymskoi liryky Lesi Ukrainky [Genre Peculiarities of Lesia Ukrainka's Crimean Lyrics]." In Lesia Ukrainka i suchasnist. Vol. 4. Book 1, 11-33. Lutsk: Volynskyi natsionalnyi universytet imeni Lesi Ukrainky, 2007.

Weintraub, Wiktor. The Poetry of Adam Mickiewicz. 's-Gravenhage: Mouton, 1954.

Welsh, David J. Adam Mickiewicz. New York: Twayne Publishers, 1966.

Yefremov, Serhii. “Poeziia samotnosti [Poetry of Loneliness].” In Literaturno-krytychni statti by Serhii Yefremov, 210-15. Kyiv: Dnipro, 1993.

Zerov, Mykola, and Andrii Muzychka. "Lesia Ukrainka. Yii zhyttia, hromadska diialnist i poetychna tvorchist [Lesia Ukrainka: Her Life, Public Activity, and Poetic Creativity]." Chervonyi shliakh 6-7 (1925): 327-30.

Zerov, Mykola. "Lesia Ukrainka." In Tvory v dvokh tomakh. Vol. 2, 359-40o. Kyiv: Dnipro, 1990. Zerov, Mykola. Lesia Ukrainka. Krytychno-biohrafichnyi narys [Lesia Ukrainka: CriticalBiographical Essay]. Kharkiv; Kyiv, 1924.

\section{讨}

Yelena Severina holds a $\mathrm{PhD}$ in Slavic Languages and Literatures from the University of California, Los Angeles. She teaches courses on Russian literature and theater at the University of California, Los Angeles. Her research and publications focus on tableaux vivants, imperial court culture, modernism, performance studies, Ukrainian and Polish theaters. Her most recent article appears in KinoKultura 65 (2019). She is a regular contributor to an online reference The Literary Encyclopedia. 